\title{
SEIDENFORCHIS - A NEW GENUS OF MALAXIDINAE (ORCHIDACEAE) FROM THAILAND
}

\author{
HANNA B. MARGOŃSKA \\ Department of Plant Taxonomy \\ and Nature Conservation, Gdansk University \\ Al. Legionów 9, 80-441 Gdańsk, Poland \\ e-mail:dokhbm@univ.gda.pl
}

(Received: January 17, 2006. Accepted: March 24, 2006)

\begin{abstract}
A new genus Seidenforchis of the subtribe Malaxidinae (Orchidaceae) from Southeast Asia is proposed. Three species are transferred from Crepidium to Seidenforchis. Keys for determination of Seidenforchis species and related genera of subtribe Malaxidinae from Asia, are proposed.
\end{abstract}

KEY WORDS: Crepidium, Malaxidinae, Malaxis, Orchidaceae, Seidenforchis, taxonomy.

\section{INTRODUCTION}

While preparing the taxonomic revision of the subtribe Malaxidinae (Orchidaceae), I had the opportunity to study G. Seidenfaden's spirit collections kept at the Botanical Museum and Library of Copenhagen University. I was able to examine materials of the genus Crepidium B1. emend. Szalch. (1995). Most species of Crepidium have previously been placed in highly polymorphic Microstylis (Nutt.) Eaton or Malaxis Sol. ex Sw. Szlachetko basing on differences in generative structure and lip morphology, included 167 species within Crepidium. Among these species were Crepidium mackinninii (Duthie) Szlach. and Crepidium propinquum (Ames) Szlach., as well. During my investigations of flower forms in Crepidium I recognize that the best place for these two species would be the section Hololobus (Schltr.) Marg. in Crepidium Bl. (2005).

According to Schlechter the section Hololobus of Microstylis (Nuttel) Eaton, included species with a 3-lobed lip, with the mid-lobe entire or split into 2 sublobes. The distal margins of the lateral lobes are entire, teethless.

Within Crepidium B1. Szlachetko (1995) recognized two sections: Crepidium and Commelinoides (Schltr.) Szlach.. Both sections, according to protologues included plants characterized, among other features, by the dentate distal margins of lip. The section Hololobus will encompass all those species of Crepidium Bl. with teethless distal margins of the lip lateral lobes.

Crepidium mackinninii (Duthie) Szlach., Crepidium propinquum (Ames) Szlach. and recently described Crepidium klimkoanae Marg. are characterised by some unusual for Crepidium features e.g.: underground pseudobulbs, and ground hugging leaf blade.
Subsequent examination of type specimens, other herbarium materials and also data from the literature, suggest that these species should be best kept separately, as a new genus for which I propose the name Seidenforchis.

\section{KEY TO SEIDENFORCHIS \\ AND CLOSELY RELATED, ASIATIC GENERA OF SUBTRIBE MALAXIDINAE}

1a. Column of gynostemium massive, short, at most slightly longer than staminodes; anther relatively small, distinctly broader than longer; anther locules opening apically or ventrally ......................................... Malaxis

1b. Column of gynostemium slender, at least twice longer than staminodes; anther large, at most slightly broader than longer; anther locules opening always ventrally ... 2

2a. Lip always simple, without separated lateral lobes and without their auricles...

3

2b. Lip always 3-lobed, with auricles of lateral lobes ..... 4

3a. Lip with distal margins always entire, ligulate to ovate in shape ... Glossochilopsis

3b. Lip with apical margins usually dentate, spatulate to flabellate in shape. Seidenfia

4a. Lip with apical margins always entire, flat, without basal cavity, at central portion only with parallel lamellae or obscurely convex; gynostemium elongate, sometimes with appendages along the dorsal part of column. Pseudoliparis

4b. Lip with distal margins usually dentate, distinctly developed central lip cavity; gynostemium with column relatively short, flat along the dorsal part .......... 5

5a. Lip with central cavity large, including the most of middle part of lip, surrounded only convexly by two, external nerves, without roof above Dienia 
5b. Lip with central cavity relatively small, surrounded by prominent ring-like callus, positioned along two, external nerves, cavity usually with roof above ........ 6

6a. Pseudobulbs aboveground; leaves several, recurved from shoot and obliquely positioned; leaf blade distinctly ascended from the surface of ground ....... Crepidium

6b. Pseudobulbs underground; leaves usually 2, rarely 1 or 3 , their blades always horizontally flattened close above to the surface of ground Seidenforchis

Seidenforchis Marg. gen. nov.

TYPE: Seidenforchis propinqua (Ames) Marg. [=Malaxis propinqua Ames, =Crepidium propinquum (Ames) Szlach., see below].

Pseudobulbi subterranei. Folia 2-3 terminales rosulata, supra solum plane procurrentes. Labellum distinctissime trilobatum, lobo centrali magno, fere dimidium labelli occupanti, e lobis lateralibus acute separato per incisuram et convexam marginem superiorem cavi centrali, apice profunde et saepe asymmetrice inciso, auriculis loborum lateralium brevibus.

Plant rather small 8--20 (45) $\mathrm{cm}$ tall. Roots appearing from the basal nodes of pseudobulbs. Pseudobulbs ovoid to rarely oblong, always underground, sheathing by 1--3 basal scales and leaf-bases, annual, whitish. Leaves 2 (rarely 1 or 3 ), usually similar in size, decussately to radically positioned. Leaf sheath more or less rigid. Leaf petiole strongly abbreviated. Leaf blade ground-hugging all the time, usually ovate (sometimes suborbicular to nearly oblong), acute to obtuse, at the base obcordate, nearly sessile, amplexicaul, slightly succulent, subplicate, the inter-spaces raised above and giving the leaf a slightly bullate appearance. Inflorescence apical; peduncle with 1 to few, short and narrow, sterile bracts; raceme many-flowered, dense, elongate with age. Floral bracts narrowly lanceolate to linear triangular acuminate to acute, persistent, deflexed, green, usually longer than ovary. Ovary and pedicel sinuate. Sepals 3-nerved, with curved backward margins. Dorsal sepals oblique. Petals 1-nerved, revolute, reflexed - in adult flowers non-visible. Lip always distinctly 3-lobed, oblong ovate to pear-shaped in outline; mid-lobe distinct, up to $1 / 3--1 / 2$ of the whole lip length, constantly its distal margin distinctly cleft for 2 sublobules; lateral lobes semiorbicular to semiobcordate, with distal margins entire, auricles triangular to broadly lunate, obtuse at apices, subparallel to convergent; central cavity deep and distinct, always surroun- ded by distinguish, nearly circular hippocrepiform convexity. Gynostemium erect, short; column stout, with a swollen ridge on inner surface extending as a thin membrane in front of anther and projecting beyond anther; staminodes oblong, fleshy, rounded to truncate, usually with distinguished minute, nodulate convexities at apex. (see Fig. 1). Anther dorsal, erect, broadly ovate to cordate, movable, with narrow connection; thecae opening ventrally, paler and brighter than the rest of the gynostemium. Rostellum erect, foveolate, thin, apically truncate; stigma enclosed by bases of the staminodes. Viscidium weakly visible. Pollinia 4, clavate, with thin, apical caudiculae. Fruit 6-ribbed, erect, capsulate, obovoid.

Etymology: Dedicated to Dr Gunnar Seidenfaden, Danish diplomat, naturalist and expert in tropical Asiatic orchids (1908-2001).

The species of Seidenforchis are characterized by specific lip form, especially morphology of central cavity and really unique habit. Form of the flower and morphology of gynostemium suggest close relation to Crepidium. However, any species of Crepidium do not produced underground, abbreviated and ovate pseudobulbs, horizontally flattened, ground hugging leaves blades and so characteristic form of cavity. Underground pseudobulbs occur sometimes within Malaxis but its gynostemium are clearly different (Szlachetko and Margońska 2002) also its lip form is dissimilar.

\section{KEY TO SPECIES \\ IN SEIDENFORCHIS}

1a. Lip pear-shaped in outline, mid-lobe separated from the lateral lobes by arcuate constriction, sublobules of mid-lobe usually asymmetrical

1b. Lip ovate in outline, mid-lobe separated from the lateral lobes by arcuate recurvature of the margins, sublobes of mid-lobe usually symmetrical..... S. klimkoanae

2a. Mid-lobe oblong, cavity semiglobular, limbate by ringshaped central convexity, central convexity disappearing befor the base of mid-lobe ............ S. mackinnonii

2b. Mid-lobe ovate, cavity lanceolate to narrowly ovate, only at apical part touching central convexity, central convexity advanced at about $1 / 3$ length of the mid-lobe. S. propiqua
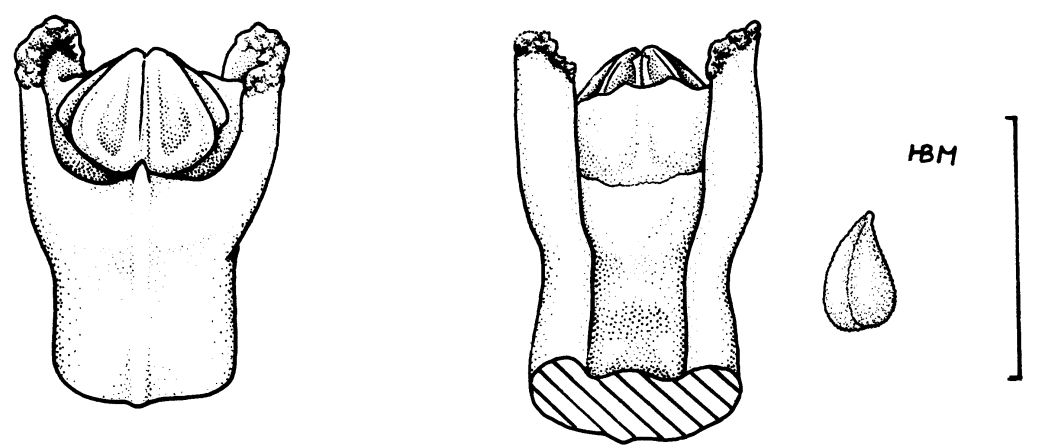

Fig. 1. Gynostemium structure in genus Seidenforchis. A - front view; B - back view; $\mathrm{C}$ - pollinia. 

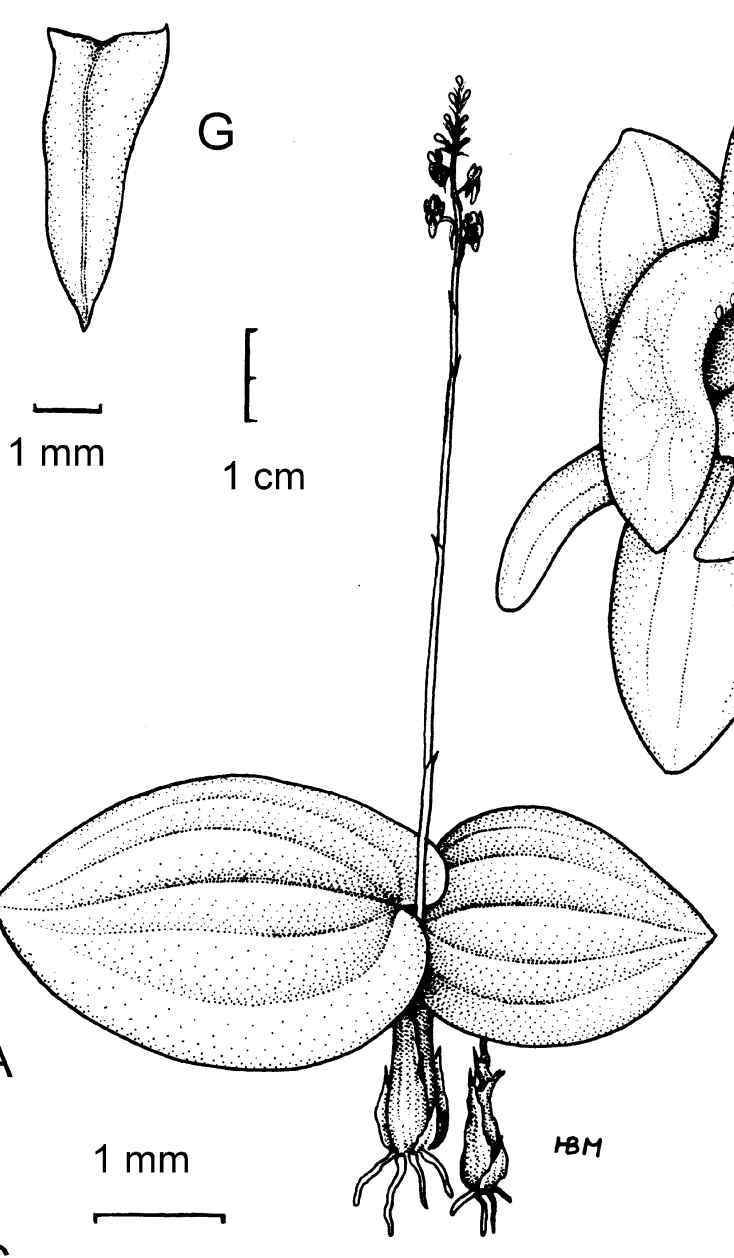

C
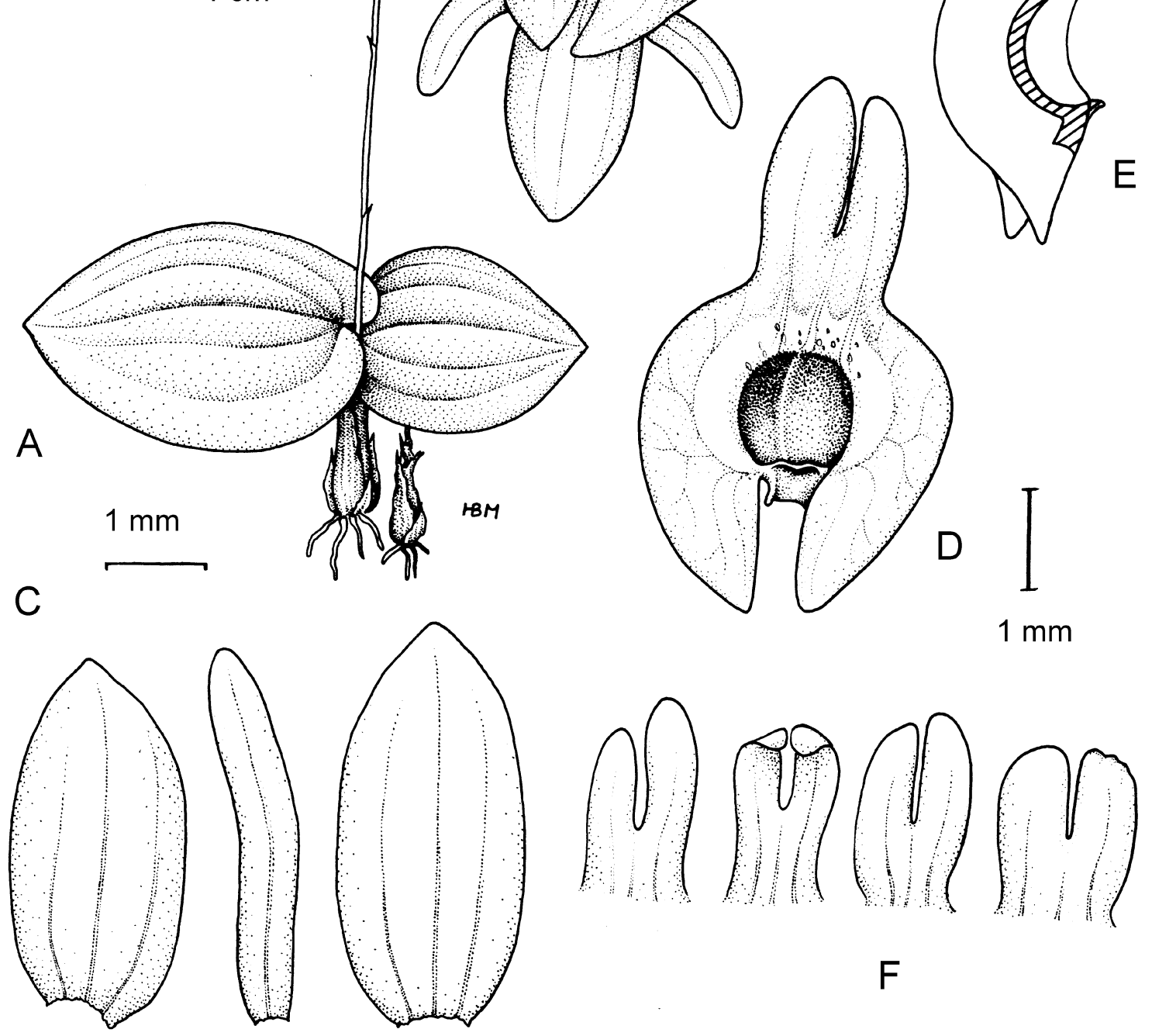

$\mathrm{F}$

Fig. 2. Seidenforchis mackinnonii. A - flowering plant; B - flower; C - tepals; D - lip; E - longitudinal section of the lip; F - different forms of the lip mid-lobe from the same inflorescence; $\mathrm{G}$ - floral bract (from the K holotype, P.W. Mackinnon 25429).

Seidenforchis mackinnonii (Duthie) Marg. comb. nov. Basionym: Microstylis mackinnonii Duthie, J. As. Soc. Beng. 71 (2): 37. 1902; Malaxis mackinnonii (Duthie) Ames, Orchidaceae 6: 289. 1920; Mal. sutepensis auct. non (Rolfe) Seidenf. \& Smitin., The orchids of Thailand 2, 1: 148. 1959; Crepidium mackinnonii (Duthie) Szlach., syn. nov., Fragm. Flor. Geobot., Suppl. 3: 128. 1995.TYPE: INDIA. Western Himalaya, Uttar Pradesh: Garhwal, Dehra Dun, Kalanga hills, P. W. Mackinnon 25429 (holotype, K) (Fig. 2). Microstylis cardonii Prain, Bengal Plants 1903: 1004 (754). 1903. - Type: India, Bengal, Chota Nagpur, Prain s.n. (holotype, CAL not seen). 
Plant 8--45 cm tall. Pseudobulbs 0.7--1 cm long, 0.4--1 (1.5) $\mathrm{cm}$ in diameter. Leaves 2 (rarely: 1 or 3); leaf sheath $0.5--1.5 \mathrm{~cm}$ long, $0.5-1.2(1.7) \mathrm{cm}$ in diameter, green grey tinged to grey; leaf petiole 0.4--0.6 (1.3) cm long, 0.3$-0.5(0.7) \mathrm{cm}$ wide when spread; leaf blade $2.8--13 \mathrm{~cm}$ long, 1.8--7 cm wide, fleshy, nerves 3--9, upper surface of lamina green to dark brownish green, often purplish to purple below. Inflorescence 12--20(40) cm long, yellowish green; peduncle 8--13 (20) cm long, (1.2) 1.5--1.8 (2) $\mathrm{mm}$ in diameter, sharply quadrangular, sometimes reddish-purple tinged; raceme 4--7 (20) cm long, 1--1.5 (1.8) $\mathrm{mm}$ in diameter, in adult inflorescence similar in length with the peduncle, 10-30-flowered, rarely thickened towards apex. Floral bracts 3--6.5 mm long, 0.6--1.5 mm wide, linear-triangular to lanceolate, acute, 1-nerved, green to yellowish green. Pedicel and ovary $2--3 \mathrm{~mm}$ long, greenish to pale greenish yellow. Flowers 5--7 mm long, 6--6.6 mm wide, reddish-purple, yellow to yellowish green, or sometimes to white. Sepals reddish-purple, green to yellow. Dorsal sepal $2.4--2.7 \mathrm{~mm}$ long, 1.2--1.5 mm wide, oblong elliptic to oblong ovate, obtuse to rounded at apex; lateral sepals $2.2--2.6 \mathrm{~mm}$ long, 1.8--2 mm wide, oblique, ovate, obtuse, revolute. Petals 2.2--2.5 mm long, 0.6--0.8 mm wide, linear to filiform, obtuse, reddish-purple to pale yellow. Lip 4.5--5.5 mm long, 2.8--3.2 mm wide, distinctly pear-shaped in outline, constricted near the middle with a raised ridge dividing the apical and basal portions; the apical portion - mid-lobe 2--2.5 $\mathrm{mm}$ long, at base 1-- $1.2 \mathrm{~mm}$ wide, the broadest near $1 / 2$ of its length $-1.2--1.4 \mathrm{~mm}$ wide, oblong, apically deeply divided (about $1 / 2$ or slightly more its length) into oblong 2-lobes (0.8-1.2 mm long, each 0.6-0.8 mm wide), often asymmetrical: different in size and shape, obtuse to rounded and revolute at the apex, mid-lobe separated from the lateral lobes by determinative, broadly triangular constriction; the basal portion $2.7--3.1 \mathrm{~mm}$ long, $2.4--2.7 \mathrm{~mm}$ wide, about orbicular, auricles ca. $1.5 \mathrm{~mm}$ long, 1--1.3 mm wide, falcately triangular, with margins contiguous and overlapping at tip; cavity characteristically semiglobular $1--1.3 \mathrm{~mm}$ long, 1--1.2 mm wide, 0.6--0.8 mm deep, surrounded by nearly circular, distinct convexity, disappearing before base of the mid-lobe; crimson-purple to pale yellow. Gynostemium 1$-1.2 \mathrm{~mm}$ long, $0.5--0.9 \mathrm{~mm}$ wide, when young greenish tinged, turn to pale yellow, sometimes reddish-purple or rarely crimson. Anther pale yellow to whitish. Capsule to $1 \mathrm{~cm}$ long, to $0.4 \mathrm{~cm}$ in diameter, obovoid, pale greenish yellow to pale yellow; stalk $0.2--0.3 \mathrm{~cm}$ long.

Ecology: Terrestrial; on stony ground, in shade; on grassy glade; in forest. Flowering between July and October. Fruiting between September to November.

Distribution: India, Nepal, Burma, China. Alt.: 600$-2.000 \mathrm{~m}$.

Representative specimens: INDIA. Uttar Pradesh: Garhwal, Dehra Dun, Mussoorie, Mackinnon 21779 (fide Duthie, 1906); 22974 (FI, P, WU), I, II (G), I, II, III (K); Rajpur, Deva 5855; Nalapani, Deva 2685 (fide Duthie 1906); Bihar and Orissa: Nijam Landakot forest, Rairakhol, Mooney 4010 (K), Sambalpur, Deb 3108 (K); Maharashtra: near Bombay, Wanghai, Dangs, Santapau and Kapadia s.n., 19088, 19142, 20000, Kapadia 688, 1421-1428 (CAL, fide Santapau and Kapadia 1966); Madhya Pradesh: Shambhudhara, Amerantak, Saxena s.n. (CAL, fide Santapau and Kapadia 1966). BURMA. West Central part: s. prec. loc. Kingdon-Ward 22598 (BM, GB).
Pobably also representing this species: NEPAL. Central part: near Chunia village, in Rapti Dun Sal forest, near Churia Khola, Sharma \& White 168 (K- only fruiting plants). CHINA. Yunnan: Ducloux 303 (P, fide Seidenfaden 1978).

Note: Santapau and Kapadia (1966) reviewed herbarium specimens kept at CAL including among others the type of Micostylis. cardoni Prain and also K with type of Micostylis. mackinnonii Duthie. Based on the morphological features they recognized those specimens of both taxa as identical, although the flowers of those plants were different in colour. I had not opportunity to examine the type of Micr. cardoni Prain (CAL). It is possible existence of two color forms of this species. However, it could be confirm only by further, particular study.

Seidenforchis propinqua (Ames) Marg. comb. nov. Basionym: Malaxis propinqua Ames, Orchidaceae 6: 289. 1920. TYPE: PHILIPPINES. Luzon: Bontoc Subprov., Bauco, M. Vanoverbergh 3916 (holotype, AMES) (Fig. 3). Crepidium propinquum (Ames) Szlach., syn. nov., Fragm. Flor. Geobot., Suppl. 3: 130. 1995.

Plant minute, $8--15 \mathrm{~cm}$ tall. Pseudobulbs $1.2--2.5 \mathrm{~cm}$ long, (0.3)0.5--0.8 (1) cm in diameter. Leaves 2 (3 rarely); leaf sheath $0.4-1(1.2) \mathrm{cm}$ in diameter, green to greenish with fulvous or even tawny tint; leaf petiole 0.2--0.4 (0.6) $\mathrm{cm}$ long, 0.2--0.4(0.5) $\mathrm{cm}$ wide when spread; leaf blade 1.5--4 cm long, 0.7--3.3 cm wide, 3--7-nerved, upper surface of lamina green to dark green. Inflorescence 5.5--12(15) $\mathrm{cm}$ long, olive to bright green; peduncle 3--5 (6) $\mathrm{cm}$ long, (1.2) 1.5--2 (2.2) $\mathrm{mm}$ in diameter, in adult inflorescence shorter than raceme; raceme 2--7 cm long, (0.8) 1--1.2 mm in diameter, 5--20 (30)-flowered, elongated with age. Floral bracts narrowly lanceolate, acuminate, green. Ovary and pedicel ca. $1 \mathrm{~mm}$ long greenish to pale greenish olive, sometimes with violet tint. Flowers 4--7 mm long, 3--5 mm wide, pinkish violet. Dorsal sepal 2.8--3.1 mm long, 0.9--1.2 mm wide, elliptic to oblong ovate, rounded at apex; lateral sepals $2.5--2.8 \mathrm{~mm}$ long, 1.9--2.2 mm wide, elliptic to ovate, obtuse, revolute. Petals ca. $2.8--3 \mathrm{~mm}$ long, 0.4--0.6 mm wide, linear, obtuse to retuse. Lip 4--5 $\mathrm{mm}$ long, 2.8--3.2 mm wide, obscurely pear-shaped, callus on the disc raised fleshy rim divided the blade into basal and apical parts; mid-lobe 1.8--2 mm long, $1.5--1.8 \mathrm{~mm}$ wide, the broadest slightly above the base, ovate in outline, apically deeply divided (about up to $1 / 2$ its length) into oblong 2-lobes (0.8--1.2 mm long, each 0.7--1 mm wide), each of them sometimes slightly asymmetrical, obtuse to rounded, slightly convergent at the apex, mid-lobe separated from the lateral lobes by gentle, arcuate constriction; lateral lobes 2.2--2.6 mm long, 2.8--3 mm wide, almost orbicular, auricles 1.2--1.5 mm long, ca. $1 \mathrm{~mm}$ wide, falcately triangular, subacute to obtuse, subparallel to nearly touching at apex; cavity 1-- $1.2 \mathrm{~mm}$ long, $0.4--0.5 \mathrm{~mm}$ wide, ca. $0.3--0.4 \mathrm{~mm}$ deep, narrowly ovate to lanceolate, distinctly limbate by convex, lateral nerves, only at apical part touching central convexity - rim nearly ovate in outline, more convex at apical portion, advanced at about $1 / 3$ length of the mid-lobe. Gynostemium 1--1.1 mm long, 0.7--0.9 mm wide, when young greenish, turn to yellowish, sometimes with violet tint. Anther pale yellow to whitish. Fruit up to $0,8 \mathrm{~cm}$ long, to $0.4 \mathrm{~cm}$ in diameter, obovoid, pale greenish yellow to pale yellow; stalk $0.2--0.3 \mathrm{~cm}$ long. 


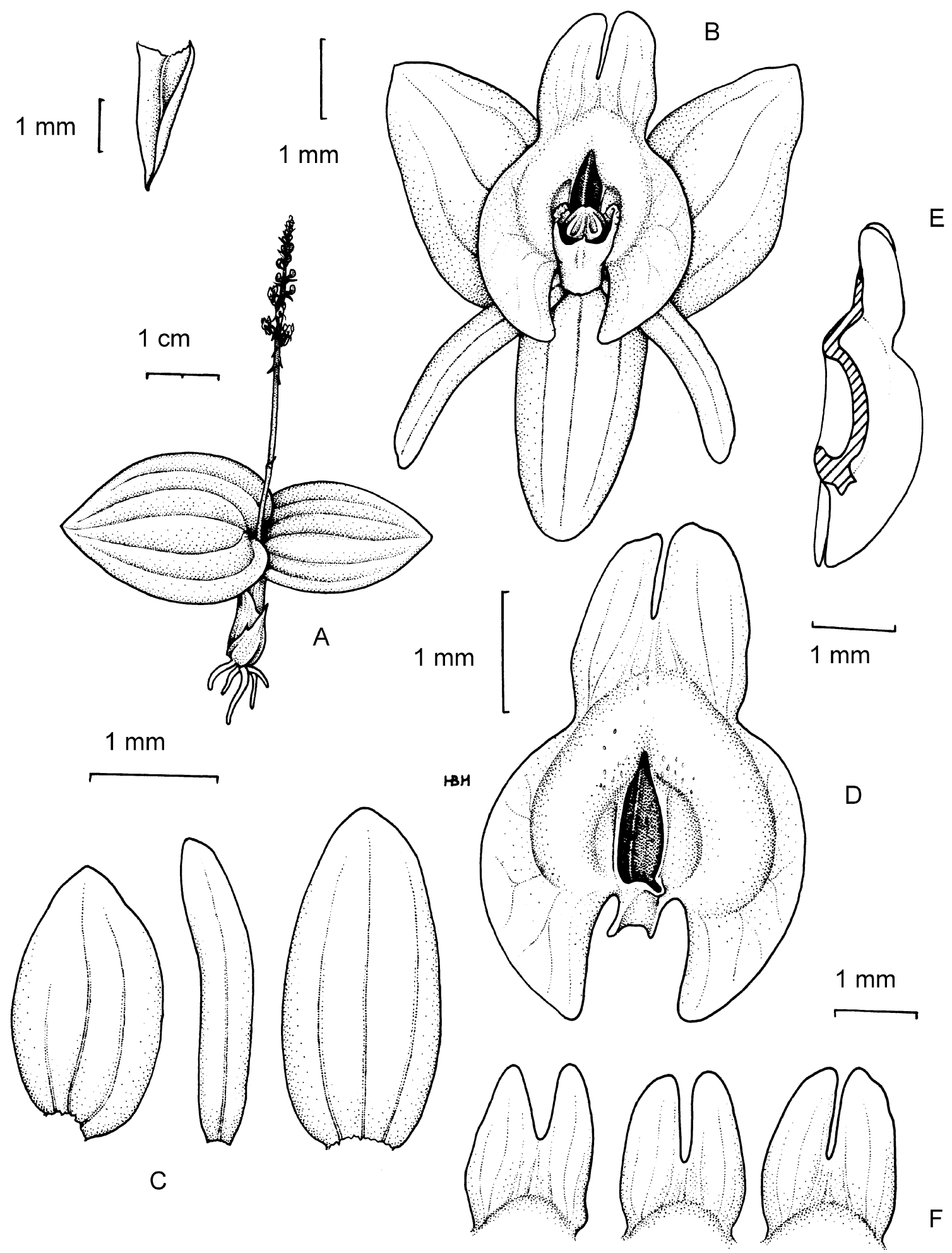

Fig. 3. Seidenforchis propinqua. A - plant with inflorescence; B - flower; C - tepals; D - lip; E - longitudinal section of the lip; F-different forms of the lip mid-lobe from the same inflorescence; G - floral bract (from the AMES holotype, M. Vanoverbergh 3916).

Ecology: Terrestrial; on hill forests. Flowering at July. Fruiting at September.
Distribution: Philippines. Endemic. Alt.: about $1.200 \mathrm{~m}$. Representative specimens: PHILIPPINES. Luzon: Bontoc Prov. (fide Valmayor 1984) 


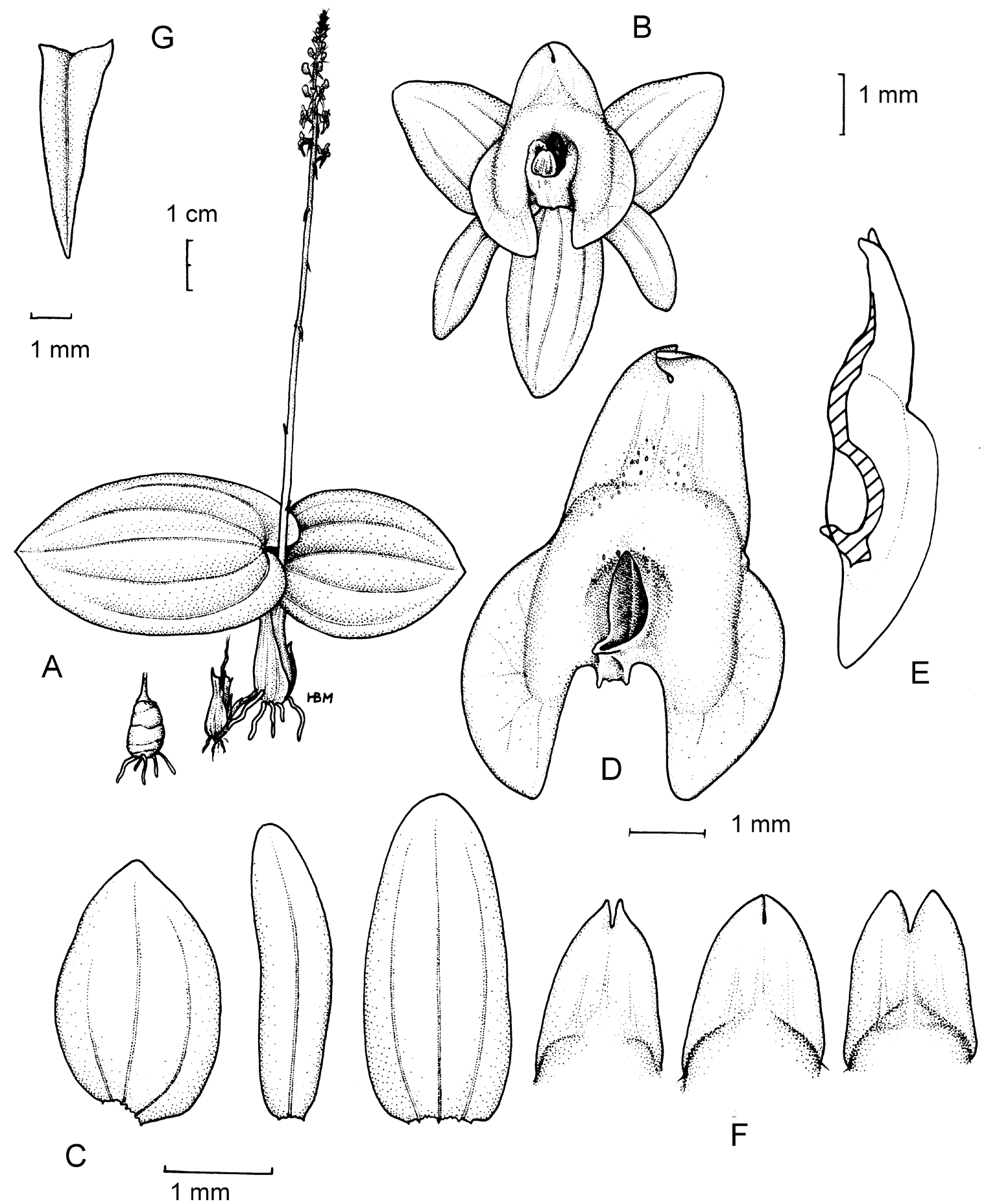

Fig. 4. Seidenforchis klimkoanae (Marg.) Marg. A - habit; B - flower; C - tepals; D - lip; E - longitudinal section of the lip; F - different forms of the mid-lobe (part of lip) from the same inflorescence; G - floral bract (from the C-GS holotype, G. Seidenfaden and T. Smitinand GT 3031).

Seidenforchis klimkoanae (Marg.) Marg. comb. nov. Basionym: Crepidium klimkoanae Marg., 2005. Candollea 60(2): 289-303. TYPE: THAILAND. Wangchao: Chiengdao, G. Seidenfaden \& T. Smitinand GT 3031 (holotype, C, C-GS - spirit. coll.) (Fig. 4).
Plant minute, $8--15 \mathrm{~cm}$ tall. Pseudobulbs 1--1.7 cm long, $0.5--0.7$ (1) $\mathrm{cm}$ in diameter. Leaves 2 (3 rarely); leaf sheath $0.6--0,8(1.2) \mathrm{cm}$ in diameter; leaf petiole $0.2--0.4(0.8) \mathrm{cm}$ long, 0.2--0.4(0.5) cm wide when spread; leaf blade 3--6 $\mathrm{cm}$ long, 2.5--4.6 cm wide, 3--5-nerved, upper surface of 
lamina green, sometimes with reddish tint below. Inflorescence $8--13 \mathrm{~cm}$ long, olive to bright green, sometimes tinged reddish; peduncle 5--8 cm long, 1.4--2 $\mathrm{mm}$ in diameter, in adult inflorescence longer than raceme; raceme 3--5 cm long, 1--1.2(1.4) $\mathrm{mm}$ in diameter, 5--15 (20)-flowered, elongated with age. Floral bracts narrowly lanceolate, acuminate, green, sometimes tinged reddish. Ovary and pedicel $2--3 \mathrm{~mm}$ long greenish to pale greenish olive, sometimes with reddish tint. Flowers 5.8--6.2 mm long, 3--5 mm wide, greenish red. Dorsal sepal 3--3.4 mm long, 1.1--1.4 $\mathrm{mm}$ wide, oblong elliptic to oblong ovate, rounded at apex; lateral sepals $2.8--3.2 \mathrm{~mm}$ long, $1.8--2.1 \mathrm{~mm}$ wide, ovate, obtuse, revolute. Petals ca. 2.7--3,2 mm long, 0.7--0.8 mm wide, oblong, oblique obtuse. Lip 4--4,5 mm long, 2.8--3.1 $\mathrm{mm}$ wide, very obscurely pear-shaped to ovate, callus on the disc raised fleshy rim divided the blade into basal and apical parts; mid-lobe 1.5--1.7 mm long, 1.3--1.5 mm wide, the broadest near the base, about triangular in outline, apically divided up to $1 / 4$ (rarely to almost $1 / 3$ ) its length, each of sublobules oblong (0.4--0.5 mm long, each 0.2--0.3 $\mathrm{mm}$ wide), usually symmetrical, obtuse to subacute, slightly convergent to overlapping at the apices, mid-lobe separated from the lateral lobes only by distinct, arcuate recurvature of the margins; lateral lobes $2--2.3 \mathrm{~mm}$ long, 2.8-$3.1 \mathrm{~mm}$ wide, orbicular to broadly obovate, auricles $1.7--$ $1.8 \mathrm{~mm}$ long, $0.8--1 \mathrm{~mm}$ wide, triangular to broadly lunate subacute to obtuse, subparallel to nearly convergent; cavity $1.1--1.3 \mathrm{~mm}$ long, 0.6--0.7 mm wide, ca. 0.4--0.5 mm deep, narrowly ovate to lanceolate, distinctly limbate by convex, lateral nerves, only at apical part touching central convexity - hippocrepiform rim nearly ovate to elliptic in outline, more convex at apical half, advanced at about 1/4-1/3 length of the mid-lobe. Gynostemium 1--1.2 mm long, 0.5$-0.9 \mathrm{~mm}$ wide, when young greenish tinged, turn to pale yellow, sometimes reddish. Anther pale yellow to whitish yellow. Capsule to $0,8 \mathrm{~cm}$ long, to $0.4 \mathrm{~cm}$ in diameter, obovoid, pale greenish yellow to pale olive; stalk $0.2--0.3 \mathrm{~cm}$ long.

Ecology: Terrestrial; in shade forest. Flowering at September. Fruiting between October and December.

Distribution: Thailand. Endemic.

Representative specimens: THAILAND. Doi Suthep, Seidenfaden \& Smitinand GT 3038, GT 3042 (C, C-GS spirit. coll.).

Note: Seidenfaden (1978) compared Thai plants (Seidenfaden \& Smitinand GT 3031, GT 3038, GT 3042) with the type of Microstylis mackinnonii Duthie (K) and recognized them as indistinguishable. I found these specimens at Seidenfaden's collection (C-GS) deposited at C. The Thai plants in fact, in many respects are similar to the type of mackinnonii Duthie e.g.: habit, underground pseudobulbs, shape and disposition of leaves, form of lip convexity and gynostemium (especially staminodes). However the specimens collected by Seidenfaden \& Smitinand have some features distinctly different from the type of mackinnonii Duthie and can be easily distinguished by peduncle similar in length or longer than raceme, lip ovate in outline, mid-lobe triangular, separated from the lateral lobes by arcuate recurvature of the margins (without any constriction), sublobules of mid-lobe small (about 1/4 length of mid-lobe), symmetrical, central convexity of the lip advanced at about $1 / 4--1 / 3$ length of the mid-lobe.

\section{ACKNOWLEDGMENTS}

I am obliged to Prof. Dr. hab. Ryszard Ochyra for the Latinization of the diagnoses. I am grateful to Dr. Olof Ryding, the Curator of $\mathrm{C}$ and the Curators of AMES, FI, GB, $\mathrm{K}$, US, WU for the loan of herbarium specimens and/or their hospitality during my personal visits. Special thanks for Mrs e. M. Kortylewska-Margońska and Mr. e. M. Margoński for help during of my researches. This article was prepared thanks to COBICE (Copenhagen Biosystematics Centre, European Commission Human Potential Programme), project no. 226.

\section{LITERATURE CITED}

DUTHIE J.F. 1906. The Orchids of the North-Western Himalaya. Ann. Roy. Bot. Gard. Calcutta. 9 (2): 87-89.

MARGOŃSKA H.B. 2005. Crepidium klimkoanae - a new orchid species (Orchidaceae, Malaxidinae), from Thailand. Candollea 60 (2): 289-303.

SANTAPAU H., KAPADIA Z. 1966. The Orchids of Bombay. Calcutta. 98-100.

SEIDENFADEN G. 1978. Orchid Genera in Thailand VII. Oberonia Lindl. and Malaxis Sol. ex Sw. Dansk Bot. Arkiv 31 (1): $1-94$

SZLACHETKO D.L. 1995: Systema Orchidalium. Fragm. Flor. Geobot., Suppl. 3: 123-133.

SZLACHETKO D.L., MARGOŃSKA H. 2002. Gynostemia Orchidalium. Vol. 2. Orchidaceae (Epidendroidea). Ann. Bot. Fen. 197 pp +287 figs.

VALMAYOR H.L. 1984. Orchidiana Philippiniana. vol. 1. E. Lopez, Manila. 240-247. 